\title{
LIVER TRANSPLANTATION: A 10-YEAR SINGLE CENTER EXPERIENCE IN PERNAMBUCO- NORTHEASTERN BRAZIL
}

\author{
Transplante Hepático: Experiência de 10 anos de um centro transplantador em Pernambuco - \\ Nordeste do Brasil
}

\begin{abstract}
Luiz Eduardo C. Miranda, Paulo Sérgio Vieira de Melo, Diego Laurentino Lima, Bernardo Sabat, Américo Gusmão Amorim, Olival Cirilo Lucena Neto, Helry Cândido Lopes, Roberto Lemos, Laécio Leitão e Cláudio Moura Lacerda
\end{abstract}

\begin{abstract}
Purpose: The aim of this study is to analyze a ten-year single center experience in liver transplantation in Pernambuco - Northeastern region of Brazil. Methods: Data were retrospectively collected from medical records of 302 patients who underwent Orthotopic Liver Transplantation (OLT) between 1998 and 2008 at Oswaldo Cruz University Hospital, Pernambuco - Brazil. We analyzed just the outcomes and survival curve of 195 adult liver transplantation recipients from deceased donor. Results: Data concern liver donor, surgery technical aspects and liver transplantation recipients' postoperative evolution are presented and discussed. This center has a significant experience in liver transplantation using conventional technique with no venovenous bypass. Efficient management of liver transplantation practice has made it feasible to keep the cold ischemia time within 6-7 hours. Because of the organ shortage, we have used a large amount of extended criteria liver donor. The survival 1-year rata was $76.4 \%$. Conclusion: It is possible to provide a high-quality public medical assistance in an efficient and continuous manner in less developed areas of Brazil.
\end{abstract}

Keywords: Transplantation; Survivorship; Liver

Instituição:

General Surgery and Liver Transplantation Service, Oswaldo Cruz General Hospital, Pernambuco University - Brazil

Correspondência:

Luiz Eduardo Correia Miranda

Serviço de Cirurgia Geral e Transplante de Fígado

Rua Arnóbio Marques, 310, CEP: 50.100-130, Recife- PE, Brasil

Tel. (+ 55 81) 31833522

Email: lecmiranda@gmail.com

\section{INTRODUCTION}

The first orthotopic liver transplantation (OLT) in Brazil was carried out in 1968. In 1993, Lecerda et al. performed the first OLT in the Northeastern region of Brazil. Since $1998,{ }^{2}$ in this large region of the nation, an effective and uninterrupted OLT center has been functioning in a university hospital (Oswaldo Cruz University Hospital - OCUH). ${ }^{1}$ Although in recent years the amount of centers providing liver transplant (LT) has significantly increased in this country, OCUH LT-Center is still the most productive and experienced across the Northern and Northeastern regions. Even today, this is the only center in that region performing OLT in children, and extensively employing conventional OLT technique with no portal systemic shunt. In this study, we presented outcomes of 302 cases which have undergone deceased and living donor LT since the program started in our center in April 1998.

\section{MATERIALS AND METHODS}

The records of 302 patients who underwent OLT in the OCUH from August 1998 to December 2008 were reviewed. All operations were carried out by the same surgical team. Patients with acute liver failure below 16 years olf, living donor transplantation, split liver transplantation, domino liver transplantation, intraoperative deaths, and incomplete records were excluded from survival and results analysis. The procedure for liver graft recovery from deceased donors followed the protocol for our standard surgical technique. The grafts were perfused using Belzer or Celsior 
solutions and packed up to the moment of the liver implant.

Liver transplant recipients underwent hepatectomy with inferior vena cava preservation (piggyback fashion) or conventional technique, both with no venovenous bypass. Conventional hepatectomy technique requires clamping of both the portal flow from the viscera and vena cava flow from the lower body, whereas the piggyback technique requires clamping of portal flow only, reducing the duration of the ischemia, since it requires one less anastomosis before reperfusion compared to the conventional technique. The use of conventional or piggyback technique was the surgeon's choice. The pedicle elements were anastomosed using standard techniques. Immunosuppression was achieved using tacrolimus, mycophenolate mofetil, and corticosteroids. We weaned patients off corticosteroids as soon as possible based on clinical and laboratory evaluations, except in cases of autoimmune hepatitis, primary biliary cirrhosis, and primary sclerosis cholangitis.

Morbidity was assessed by analyzing the incidence of biliary, vascular, septic, and renal complications within 6 months after LT. Acute renal failure was considered if recipients required hemodialysis. Biliary complications were defined by stenosis if a decrease in biliary duct diameter could be confirmed by cholangiography or magnetic resonance image (MRI) of the biliary duct in the presence of clinical or laboratorial cholestasis, biliary leakage if peritoneal bile collection was diagnosed at reoperation, abdominal computerized tomography (CT) or ultrasound. Portal and hepatic artery thrombosis was diagnosed using abdominal ultrasound and hepatic arteriography, respectively, during routine tests or under clinical suspicion. Sepsis was identified whenever a life-threatening clinical state was caused by an established and attested infection disease. Primary liver failure was diagnosed if there was a liver retransplant indication, and primary dysfunction was identified whenever there was transaminase level of $>2000$ IU, both until 7 days following the first LT.

An extended criteria liver scoring system, as suggested by Briceño was used to assess the graft conditions: age of the donor $>60$ years, ICU stay $>4$ days, cold ischemia times $>13 \mathrm{~h}$, hypotensive episodes $<60 \mathrm{mmHg}$ and $>1 \mathrm{~h}$, bilirubin $>2.0 \mathrm{mg} / \mathrm{dl}, \mathrm{ALT}>170 \mathrm{U} / \mathrm{l}$, and AST $>140 \mathrm{U} / 1,{ }^{3}$ and were scored with the value of 1 . The use of $>10 \mu \mathrm{g} /$ $\mathrm{kg} / \mathrm{min}$ dopamine doses and $>155 \mathrm{mEq} / 1$ peak serum sodium were labeled with a value of 2 . We considered the graft to be an extended criteria graft when the score reached 3 (i.e., $\geq 3$ ).

The cumulative patient's survival rate was calculated according to the Kaplan-Meyer method. Data of surgical periods were shown as mean and standard deviation or median and range, when appropriate. Calculation was performed using the Prism 4.0 software (GraphPad, San Diego, California, USA).

\section{RESULTS}

A total of 302 patients underwent OLT during such period. Among the 302 cases, $195(64.5 \%)$ cases underwent OLT with graft obtained from deceased donors and were considered to the analysis of survival and results. The causes of exclusion and the LT category are listed in Table 1. Brain traumatic injury and brain hemorrhage were the most common causes of brain death (Table 2). We used 63.5\% of extended criteria grafts, i.e., grafts with Briceño scoring system of $\geq 3131(67.2 \%)$ of LT male recipients. The patients' diagnostics are listed in Table 3. It can be observed that viral hepatitis is the most significant diagnostic among liver graft recipients. In $64.1 \%$ of all cases, OLT using conventional techniques with no venovenous shunt was the surgeon's choice for most severe cases (Table 4), which may be due to the fact that the surgical team felt comfortable using this technique. Furthermore, a short cold ischemia time (Table 4) is result of a high degree of surgical planning and strong cooperation among members of the surgical team. Reoperation was carried out under postoperative bleeding, hepatic abscess, and ischemic necrosis of the liver cases (Table 5). Postoperative complications are shown in Table 5, and the overall 1-year patient survival rate was $76.4 \%$ (Figure 1).

Table 1 - Liver transplantation category and causes of exclusion

\begin{tabular}{|l|c|}
\hline Parameters & $\mathrm{n}$ \\
\hline Decesead donor - Adult & 195 \\
\hline OLT recipient under 16 year-old & 59 \\
\hline Acute liver failure & 8 \\
\hline Intraoperative deaths & 3 \\
\hline Living donor Liver transplantation & 2 \\
\hline Portocaval hemi transposition & 2 \\
\hline Split liver transplantation & 10 \\
\hline Sequential liver transplantation & 5 \\
\hline Double transplant (Liver/Kidney) & 15 \\
\hline Retransplantation & 2 \\
\hline Incomplete data & 10 \\
\hline
\end{tabular}

Table 2 - Liver donor demographic data

\begin{tabular}{|l|c|}
\hline Parameters & $n$ \\
\hline Donor causes of death & 195 \\
\hline Brain hemorrhage & $100(53.2 \%)$ \\
\hline Traumatic Brain Injury & $67(35.6 \%)$ \\
\hline Others & $21(11.2 \%)$ \\
\hline Age (yr) & $36.7 \pm 14.4$ \\
\hline Weight (kg) & $68.4 \pm 14.2$ \\
\hline Graft macrosteatosis & $68(34.8 \%)$ \\
\hline Graft weight & $1.477 \pm 370 \mathrm{~g}$ \\
\hline Graft weigth/ recipient weight & $2.15 \pm 0.78$ \\
\hline
\end{tabular}

Continuous data are present as mean $\pm S D$ 
Table 3 - Hepatic liver transplantation recipients demographic data

\begin{tabular}{|l|c|}
\hline Liver transplantation recipient diagnostic & $\mathbf{N}(\%)$ \\
\hline Viral hepatitis & $52(26,7 \%)$ \\
\hline Hepatocarcinoma & $47(24,1 \%)$ \\
\hline Alcohol cirrhosis & $32(16,4 \%)$ \\
\hline Cholestatic disease & $19(9,7 \%)$ \\
\hline Cryptogenic cirrhosis & $22(11,3 \%)$ \\
\hline Others & $23(11,8 \%)$ \\
\hline Gender & \\
\hline Male & $131(67.2 \%)$ \\
\hline Age $(Y r)$ & $50.31 \pm 13.6$ \\
\hline Weight (kg) & $71.2 \pm 15.8$ \\
\hline IMC & $25.9 \pm 4.6$ \\
\hline ABO blood & \\
\hline O & $88(45.1 \%)$ \\
\hline A & $77(39.5 \%)$ \\
\hline B & $21(10.8 \%)$ \\
\hline AB & $09(4.6 \%)$ \\
\hline Child-Pugh Class & \\
\hline A & $15.8 \pm 5.2$ \\
\hline B & $90(20.5 \%)$ \\
\hline C & \\
\hline MELD & $(30,8 \%)$ \\
\hline
\end{tabular}

Table 4 - Operative characteristics

\begin{tabular}{|l|c|}
\hline Parameters & N \\
\hline Type of surgery & \\
\hline Conventional technique without venovenous bypass & $125(64,1 \%)$ \\
\hline Piggyback technique & $70(35,9 \%)$ \\
\hline Biliary anastomosis & \\
\hline Choledochocholedochostomy without T tube & $157(80.5 \%)$ \\
\hline hepaticojejunostomy & $38(19.5 \%)$ \\
\hline Surgical time & \\
\hline Operative time & $6 \mathrm{~h} 51 \mathrm{~min} \pm 2 \mathrm{~h} 6 \mathrm{~min}$ \\
\hline Cold ischemia time & $6 \mathrm{~h} 17 \mathrm{~min} \pm 2 \mathrm{~h} 23 \mathrm{~min}$ \\
\hline Warm ischemia time & $51 \mathrm{~min} \pm 15 \mathrm{~min}$ \\
\hline Blood Transfusion Requirement & (units) \\
\hline Packed Red Blood Cell & $3,9(0-27)$ \\
\hline Fresh Frozen Plasma & $5,1(0-32)$ \\
\hline Platelet (units) & $4,4(0-30)$ \\
\hline
\end{tabular}

Surgical times are presented as mean $\pm S D$; Blood transfusion requirement are presented as median (range).

Surgical time, total operation time - from incision until closure of the abdomen: cold ischemia time - from the in situ infusion of the donor organ until the liver is removed for ice for implantation; Warm ischemia time - time between the liver is removed from ice untiluntil reperfusion via portal vein.
Table 5 - Postoperative evolution

\begin{tabular}{|l|c|}
\hline Parameter & $\begin{array}{c}1 \% 5^{\circ} \text { postoperative day } \\
\text { (mean } \pm \text { SD) }\end{array}$ \\
\hline AST (U/L) & $1352.7 \pm 2208.6 / 134.4 \pm 197$ \\
\hline ALT (U/L) & $890.5 \pm 1.039 .6 / 440.7 \pm 497$ \\
\hline Prothrombine time (INR) & $2.30 \pm 1.0 / 1.3 \pm 0.4$ \\
\hline Creatinine (mg/dL) & $1.18 \pm 0.8 / 1.37 \pm 1.0$ \\
\hline Orotracheal tube withdrawn time & N \\
\hline Immediately & $51(26 \%)$ \\
\hline Less than 6 hour & $63(32.8)$ \\
\hline Between 6 and 12 hours & $42(21.9 \%)$ \\
\hline More than 12 hours & $36(18.4 \%)$ \\
\hline Complications & $19(8.25 \%)$ \\
\hline Sepsis & $14(7.1 \%)$ \\
\hline intra-cavitary postoperative Bleeding & $5(2.5 \%)$ \\
\hline Biliary leakage & $18(9.2)$ \\
\hline Biliary stenosis & $14(7.22 \%)$ \\
\hline Hepatic artery thrombosis & $3(1.55 \%)$ \\
\hline Vena Porta thrombosis & $20(10.2 \%)$ \\
\hline Reoperation (not bleeding) & $3(2.58 \%)$ \\
\hline Primary liver failure & $8(4.1 \%)$ \\
\hline Primary dysfunction & $18(9.7 \%)$ \\
\hline Acute renal failure & \\
\hline
\end{tabular}

Figure 1 - One-year-patient survival curves for liver transplantation recipients.

\section{Survival of 1 ano:Survival proportions}

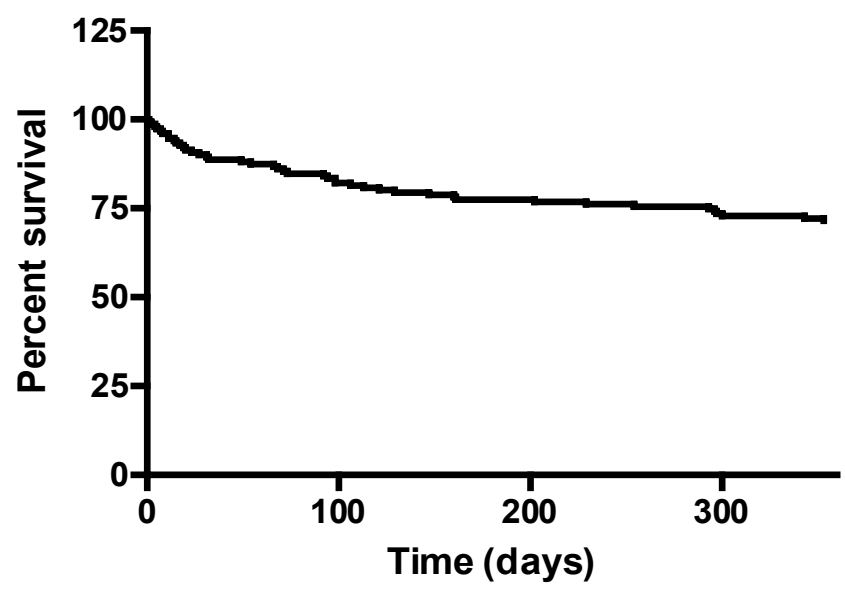

\section{DISCUSSION}

This retrospective study included a series of patients who underwent OLT up to December 2008 in the first LT center located in the poorest region of Brazil. We worked in a public hospital, thoroughly 
paid by public resources and providing medical assistance to the poorest layer of the society. There are many markers characterizing the profile of this single center. We analyzed only the outcomes of adult LT recipients from deceased donors to reduce bias. Currently, this is the only LT center all over the Northern/Northeastern Brazil, performing LT in children. ${ }^{4}$ Children from the poorest region of the country who had moved to more developed states in Brazil in order to achieve medical care have now a medical center where they can attain means to their disease. Although this fact represents an important improvement in medical and social assistance for these children often from unassisted families, only 56 of them were transplanted by us in the last 10 years. This fact can be explained by the severe shortage of organ donors compatible with the children's weight. This issue has been partially managed by the implementation of the Meld criteria for organ allocation since July 2006, which has favored children on the waiting list for organ donation.

This LT center has a significant experience, using conventional technique without venovenous bypass, because in the early days of its conception, many logistic restrictions had to be overcome. Believing that liver transplantation could be safely done with no venovenous by pass,${ }^{5,6}$ this surgical team was encouraged to initialize the liver transplantation program even though a venovenous bypass could not be carried out due to technical constraints. Thus, with the increasing experience in using such technique, it became the most frequent and safe option to be employed by the surgical team, even when dealing with the most severe cases. In our records, we have not observed severe complications resulting from OLT using conventional technique without venovenous bypass, when compared with OLT using piggyback technique. ${ }^{5}$

Furthermore, we attained a rather short cold ischemia time. Although the scientific publication on LT sets that cold ischemia time can be extended up to $14 \mathrm{~h}$ using Belzer or Celsior solutions without posing a harm to the graft or to the OLT outcome, ${ }^{7-10}$ we effectively believe that shortening of the cold ischemia time can improve outcomes of the OLT. Hence, we strived to reduce the cold ischemia time through a well-organized synchronization between the liver donors' surgery and the recipient LT. This efficient management of LT practice made it feasible to keep the cold ischemia time within $6-7 \mathrm{~h}$.

The 1-year survival rate was $76.4 \%$, which is lower than the ones demonstrated by top LT centers around the world. ${ }^{11}$ Nevertheless, we presume that if data survival after OLT is right, it is indispensable considering the mortality on the waiting list for organ donation. Thus, in order to decrease mortality on the waiting list, we employed extended criteria liver donors. This medical option is strongly based on published data certifying that patients who suffer from terminal liver disease can benefit from LT even using grafts from extended criteria donors. ${ }^{12,13}$ Although this OLT policy may have a beneficial effect over the waiting list mortality by offering a chance of OLT to more patients, it may have some impact over 1-year survival after OLT, because more severe patients may receive a graft that may not be the optimum choice.

Complications, primary liver failure, need of blood products, and in-hospital time observed in our study were not different from those published in earlier studies. ${ }^{14-18}$ This transplantation center has witnessed few cases of live donor and split OLT. Ethical reasons concerning live donor safety have limited the indication of this kind of OLT in a few cases, and split LT may probably be a good choice to increase the pool of grafts to OLT in the near future. Besides, our center has the same difficulties as others in Asia and in the rest of Latin America, such as shortage of deceased donor liver grafts, lack of financial coverage, education and organization. ${ }^{19,20}$ Furthermore cultural and religious barriers restrict the amount of transplants in Asian centers. ${ }^{21}$

\section{CONCLUSIONS}

Although this study has a few limitations, including the fact that it was a retrospective study, it has an interesting historical significance. Here, we reported the 10-year outcomes of the first LT center functioning in the less developed region of Brazil. It is amazing to note that just 11 years ago, patients needing LT all over the Northern/Northeastern parts of Brazil had no other treatment option than going to centers located in more developed Brazilian states or even abroad. Thus, the results discussed here support the conclusion that it is feasible to provide a high-quality public medical assistance in an efficient and continuous manner in less developed areas of Brazil.

\section{RESUMO}

Objetivo: O objetivo deste estudo é analisar a experiência de 10 anos de um centro transplantador em Pernambuco, nordeste do Brasil. Métodos: Dados foram retrospectivamente coletados de arquivos médicos de 302 pacientes que foram submetidos a um transplante ortotópico de fígado entre 1998 e 2008 no Hospital Universitário Oswaldo Cruz, Pernambuco, Brasil. Analisamos apenas os resultados e curva de sobrevida de 195 transplantes hepáticos com receptores adultos de doadores falecidos. Resultados: Dados relacionados ao doador de fígado, aspectos técnicos da cirurgia e evolução pós-operatória dos pacientes transplantados são apresentados e discutidos. Esse centro tem uma experiência significante em transplante hepático usando a técnica convencional sem bypass venovenoso. O manejo eficiente da prática do transplante hepático tornou factível permitir a isquemia fria dentro de seis a sete horas. Devido à escassez de órgãos, usamos uma grande quantidade de critérios estendidos de doador de fígado. Conclusão: É possível proporcionar assistência médica pública de alta qualidade de forma eficiente e contínua em áreas menos desenvolvidas do Brasil.

Descritores: Transplante; Sobrevida; Fígado. 


\section{REFERÊNCIAS}

1. Mies S, Massarollo PC, Baia CE, Kallas MR, Raia S. Liver transplantation in Brazil. Transplant Proc. 1998;30(6):2880-2.

2. Lacerda CM, Sette M, Maia M.. Carcinoma fibromelar recidivado. O primeiro caso de transplante de fígado no Recife. Na Fac Med Univ Fed Pernamb. 1994;39(2):124-8.

3. Briceño J, Solórzano G, Pera C. A proposal for scoring marginal liver grafts. Transplant Int. 2000; 13[Suppl 1]: S249-S252.

4. Neto OCLF, Amorim A, Sabat B. Transplante de Fígado em crianças: resultados iniciais do Hospital Universitário Oswaldo Cruz, Universidade de Pernambuco. An Fac Med Univ Fed Pernamb. 2005;50(1):19-22.

5. Melo PSV. Transplante Ortotópico de Fígado Sem Desvio Veno-venoso. Comparação entre as técnicas convencional e Piggyback. [Tese doutorado] Recife: Centro de Ciências da Saúde da Universidade Federal de Pernambuco; 2009.

6. Khan S, Silva MA, Tan YM, John A, Gunson B, Buckels JA, et al. Conventional versus piggyback technique of caval implantation; without extra-corporeal venovenous bypass. A comparative study. Transplant Int. 2006;19:795-801.

7. Isern Mr, Massarollo PC, de Carvalho EM, Baía CE, Kavakama J, de Andrade Lima $\mathrm{P}$, et al. Randomized Trial comparing pulmonary alterations after conventional with venovenous bypass versu piggyback liver transplantation. Liver Transplant. 2004;10:425.

8. Lerut JP, Molle G, Donataccio M, De Kock N, Ciccarelli, O, Latterre PF, et al . Cavocaval liver transplantation without venovenous bypass and without temporary portocaval shunting: the ideal technique for adult liver grafting? Transplant Int. 1997;10:171.

9. Shokouh-Amiri MH, Grewal HP, Vera SR, Stratta RJ, Riely CA, Fleckenstein, JF, et al. Eighteen years of experience with adult and pediatric liver transplantation at the University of Tennessee, Memphis. Clin Transpl 2000; 14:255.

10. Hesse UJ, Berrevoet F, Troisi R, Pattyn P, Mortier E, Decruyenaere J, et al. Hepatovenous reconstruction in orthotopic liver transplantation with preservation of the recipients inferior vena cava and veno-venous bypass. Langenbeck's Arch Surg. 2000;385:350-6.

11. Gleisner AL, Muñoz A, Brandao A, Marroni C, Zanotelli ML, Cantisani GG, et al.
Survival benefit of liver transplantation and the effect of underlying liver disease. Surgery. 2010; 147(3):392-404.

12. Bacchella T, Galvão FHF, Almeida JLJ, Figueira ER, Moraes A, Machado MCC. Marginal grafts increases early mortality in liver transplantation. Sao Paulo Med J. 2008;126(3):161-5.

13. Pokorny H, Langer F, Herkner H, Schernberger R, Plöchl W, Soliman T, et al. Influence of cumulative number of marginal donor criteria on primary organ dysfunction in liver recipients. Clin Transplant. 2005 Aug;19(4):532-6.

14. Ravaioli M, Grazi GL, Dazzi A, Bertuzzo V, Ercolani G, Cescon M, et al. Survival benefit after liver transplantation: a single European center experience. Transplantation. 2009;88(6):826-34.

15. Miyamoto S, Polak WG, Geuken E, Peeters PM, de Jong KP, Porte RJ, et al. Liver Transplantation with preservation of the vena cava. A comparisom of conventional and piggyback techniques in adults. Clin Transplant. 2004;18:686.

16. Massicotte L, Sassine MP, Lenis S, Seal RF, Roy A. Survival rate changes with transfusion of blood products during liver transplantation. Can J Anaesth. 2005;52(2):148-55.

17. Boin IFSF, Leonardi MI, Udo EY, Sevá-Pereira T, Stucchi RSB, Leonardi LS. Aplicação do Escore MELD em pacientes submetidos a transplante de fígado - análise retrospectiva da sobrevivência e dos fatores preditivos a curto e longo prazo. Arq Gastroenterol. 2008; 45(4):275-83.

18. Vianna RMM, Nery JR. Transplante hepático. In: Kalil AN, Coelho JH, Strauss E. Figado e vias biliares: Clínica e Cirurgia. 1 ed. Rio de Janeiro - RJ: Revine; 2001.p.479-506

19. Schiano TD, Rhodes R. Transplant tourism. Curr Opin Organ Transplant. 2010; 15(2):245-8.

20. Lo CM. Liver transplantation in Asia - challenges and opportunities. Asian J Surg 2002;25:270.

21. de Villa V, Lo CM. Liver transplantation for hepatocellular carcinoma in Asia. Oncologist 2007;12:1321-31 